\title{
TRANSLATION TECHNIQUES IN MEDAN AND DELI SERDANG TOURISM BOOKLET
}

\author{
*Misdahlia Sasmita \\ **Dra. Masitowarni Siregar, M.Ed. \\ **Neni Afrida Sari Harahap, S.Pd., M.Hum.
}

\begin{abstract}
This study aims to find out the translation techniques, the dominant one used by the translator in translating the booklets and the process of translating the dominant technique. It uses the theory of Molina and Albir, which are adaptation, amplication, borrowing, calque, compensation, description, discursive creation, established equivalent, generalization, linguistic amplication, linguistic compression, literal translation, modulation, particularization, reduction, substitution, transposition, and variation. In analyzing the data, the research was conducting by using mixed method research which involved collecting both quantitative and qualitative data. The data were taken from "Medan and Deli Serdang Tourism Booklet" which consist of Bahasa and translate into English. In Medan Tourism Booklet the result of literal translation 136 sentences $(81,43 \%)$ belongs to dominant technique that applied in the booklet, followed by transposition 13 sentences $(7,78 \%)$, adaptation 8 sentences $(4,80 \%)$, borrowing 3 sentences $(1,80 \%)$, amplification 2 sentences $(1,20 \%)$, description 2 sentences $(1,20 \%)$, reduction 2 sentences $(1,20 \%)$ and generalization 1 sentence $(0,60 \%)$. In Deli Serdang Tourism Booklet the result of literal translation 61 sentences $(79,22 \%)$ belongs to dominant technique that applied in the booklet, followed by transposition 7 sentences $(9,09 \%)$, reduction 3 sentences $(3,89 \%)$, discursive creation 2 sentences $(2,60 \%)$, particularization 2 sentences $(2,60 \%)$, adaptation 1 sentence $(1,30 \%)$ and borrowing 1 sentence $(1,30 \%)$. There are three process in translating the dominant technique 1) analysis, 2) transfer and 3) restructuring.
\end{abstract}

Keywords: Translation Techniques, Tourism, Booklet 


\section{INTRODUCTION}

English has a prominent role as an international language around the world. English as an international language is the most important language used by a great number of people in many parts of the world.The globalization of modern life nowadays makes people think that they have to master a foreign language in order that they can communicate with everyone from everywhere. To master the foreign language, they need to know about translation.

Translation is one of the branches of applied linguistic as part of the activities in communication among people with different languages. Translation deals with changing the form of Source Language (SL) into Target Language (TL).

According to Newmark (1981:7), "translation is craft consisting in the attempt to replace a written message and or statement in one language by the same message and/or statement in another language". Craft here means the result of the translator in translating the text. So, the result of the translation must have same meaning between the source language (SL) and target language (TL). Translation can not be separated from learning two languages which is Bahasa and English in this study, so that the translation could get an equivalent meaning between SL and TL.

The important thing done by a translator to achieve the equivalence of both informations in source language (SL) and target language (TL) is to have techniques in translating. The applying of translation technique can find in 
booklet. Booklet is a media that used to promote product, place or the other and also persuade the reader.Booklet that can find easily nowadays is tourism booklet.The tourism booklet that chosen for this research is Medan Tourism Booklet and Deli Serdang Tourism Booklet. The booklets consist of two languages i.e. Bahasa and English where the English is the translation from Bahasa.

This study focused on the techniques used by implement of the theory propose by Molina and Albir. Molina and Albir (2002:509) propose 18 techniques (strategy that has been applied in the translation product) which usually used by the translators. These techniques are also clarification of previous clarification of the strategy, procedures, and technique of translation. The tranlastion techniques are: Adaptation, amplication, borrowing, calque, compensation, description, discursive creation, established equivalent, generalization, linguistic amplication, linguistic compression, literal translation, modulation, particularization, reduction, substitution, transposition, and variation.

\section{REVIEW OF LITERATURE}

\section{Translation}

Translation has been defined in many ways by many linguistic experts from time to time, depending on how they view the language and translation. The basic defenition of translation is the process of transfering the ideas from source 
language to target language without changing the meaning of the source language. The defenition of translation according to expert may be similar or different.

Newmark (1998:5) states that translation as rendering the meaning of a text into another laguage in the way that the author intended the text. It means that the translator must be able to transfer the meaning as close as the author's intention. It is not allowed for a translator to make new meaning or message because the translator will make the reader misunderstanding to the intention message of the author.

Pinchuck in Nhia (2011:2) states that translation is a process offinding a Target Language (TL) equivalent for a Source Language (SL) utterance. The equivalence in translation is the closest target language with thesource language that is used by the translator in the process of translation. The equivalence in translation can be also reached by mastering the language skill, in this case to find an equivalence people need to study some linguistics theories relate to the translation study before doing the translation work.

\section{Process of Translation}

According to Nida and Taber (1982:33) the good translation should follow the steps of process. There are three process of translation: analysis, transfer and restructuring. Analysis, in which the surface structure is analyzed in terms of the grammatical relationship and the meaning of the words and combination words. In this process the translator analysis the message of the source language into its simplest and structurally clearest forms. Transfer, in which the analyzed material is transferred in the mind of the translator from 
source language to target language.Restructuring, in which the transferred material is restructured in order to make the final message fully acceptable in the receptor language.

\section{Translation Techniques}

According to Molina and Albir (2002:509), they define translation technique as procedures to analyze and classify how translation equivalence works. Translation techniques are very important in order to get the good result of translation. A translator must be master in translation techniques, so the translator can deliver the message from source language to target language well. And the readers can catch and understand the meaning in target language easily.

Molina and Albir (2002:509) propose 18 techniques, these techniques are also clarification of previous classification of strategy, procedure, and technique of translation. The translation techniques are Adaptation, amplification, borrowing, calque, compensation, description, discursive creation, established equivalent, generalization, linguistic amplification, linguistic compression, literal translation, modulation, particularization, reduction, substitution, transposition, and variation.

\section{Tourism}

WTO in Vannarith (2010: 85) defined tourism as the activities of persons traveling to and staying in places outside their usual environment for not more than one consecutive year for leisure, business and other purposes. From the 
definition, tourism is not only for leisure. If you go to the other place that is not usual for you for some reasons it can be a tourism for you.

Tourism means the temporary short-term movement of people to destinations outside the places where they normally live and work, as well as their activities during their stay at these destinations. It should be noted that all tourism should have some travel, but not all travel is tourism.

\section{Booklet}

Booklet is a small book usually having a paper cover. Therefore, booklet is a book often with paper covers. There are many kinds of booklet. The boklet has the same function like brochure. Booklet is one of the brochure's types. The word "brochure" is often used as a synonym for "booklet," but this is incorrect. A brochure is a single piece of paper whereas the term "booklet" refers to multiple brochures being bound together. Most catalogs, corporate profiles and presentations are booklets.

\section{Medan Tourism Booklet}

Medan Tourism Booklet is a perfect booklet that contain places that can visited by the tourist in Medan. The booklet promoted the Medan's ideal. The booklet also give many informations to the tourist. The information help the tourist in visiting Medan. The booklet consist of 30 places that become tourism destination in Medan, hotel, restaurant, and Medan Map. The 30 tourism destinations that can visited by tourist are : Raya Mosque, Immanuel Church, East Mountain Temple, Shri Mariamman Temple, Graha Maria Annai Velangkani Shrine, Foodcourt Pagaruyung, Amaliun Foodcourt, Ocean Pacific, Restaurant 
Tip Top, Ucok’s Durian, Ramadhan Fair, Merdeka Walk, Rumah Makan Garuda, Lembur Kuring, Mie Aceh Titi Bobrok, Bika Ambon, Istana Maimoon, Tirtanadi Tower, North Sumatra Fair, Rahmat International Wildlife Gallery, Crocodile Park, Kesawan, Sumatera London's Building, Post Office, Military Museum, China City Artifact, Lake Siombak, Ahmad Yani Park, Tjong A Fie, Medan Zoo, and Pasar Ikan Lama.

\section{Deli Serdang Tourism Booklet}

Deli Serdang Tourism Booklet is a perfect booklet that contain places that can visited by the tourist. The booklet promoted the Deli Serdang's ideal. The booklet also give many informations to the tourist. The information help the tourist in visiting Deli Serdang. The booklet consist of 24 places that become tourism destination in Deli Serdang, vision \& mision, tourism map, hotel and restaurant and region information. The 24 tourism destnation that can visited by the tourist are : Lake Linting, Two Colors Waterfall, Biodiversity Park, Beaches, Cemara Asri's Culinary, Center of Pottery, Paragliding, Bagan Percut's Culinary, Sembahe, Sungai Dua Rasa, Armaya nature tourism, Kampung Ladang, the Hill Hotel and Resort, Agriculture Park, Flower Market, the First Protestan Chruch, Sampuran Putih Waterfall, Regional Craft Council of Deli Serdang, Museum, PTPN II, Sultan Basyaruddin Grand Mosque, Balai Datuk Setia, Siba Island, Natural Bathing Spot. 


\section{RESEARCH METHOD AND FINDINGS}

\section{Method}

In designing this research, mixmethods research was applied.Creswell (2014 : 5) defines mixed methods research as an approach to inquiry involving collecting both quantitative and qualitative data, integrating the two forms of data, and using distinct designs that may involve philosophical assumptions and theoretical frameworks.

It focused on number of translation techniques use in Medan and Deli Serdang Tourism Booklet. The analysis is qualitatively explain in detail phenomenon based on Molina and Albir's theory and find out the number of the translation techniques used in brochure and booklet quantitatively.

The data were collected by :

1. Obtaining Medan and Deli Serdang Tourism Booklet.

2. Reading the texts in Medan and Deli Serdang Tourism Booklet.

3. Finding and classifying all sentences in Medan and Deli Serdang Tourism Booklet

After collecting the data by using the technique explained, all data analyzed by using the 18 translation techniques proposed by Molina and Albir by the following steps:

1. Comparing each sentence from Bahasa to translated version by checked the dictionary to figure out the translation techniques. 
2. After comparing the ST and TT and figure out the translation technique, classifying the translation techniques applied based on Molina and Albir's theory.

3. After classifying the translation technique and find the result, describing the translation techniques by using the requirement according to Molina and Albir's theory.

4. Find out the dominant translation technique used in sentences of Medan and Deli Serdang Tourism Booklet

5. After finding the dominant technique. Describing the process of the translation in translating the dominant technique.

6. Drawing conclusion to conclude the result of the research.

7. Those steps are applicable to applied in analyzed data in Medan and Deli Serdang Booklet.

Findings

After analyzing the translation technique in Indonesian into English booklets "Medan Tourism Booklet" and "Deli Serdang Tourism Booklet", the findings can be presented as follows:

1. There are ten translation techniques applied in Medan and Deli Serdang Tourism Booklet of Indonesian and English version. Adaptation (3,69\%), Amplification (0,82\%), Borrowing (1,64\%), Description (0,82\%), Discursive Creation $(0,82 \%)$, Generalization $(0,41 \%)$, Literal Translation 
$(80,74 \%)$, Particularization $(0,82 \%)$, Reduction $(2.05 \%)$ and Transposition $(8,20 \%)$.

2. In Medan Tourism Booklet, they are Adaptation (4,80\%), Amplification $(1,20 \%)$, Borrowing (1,80\%), Description (1,20\%), Generalization (0,59\%), Literal Translation (81,43\%), Reduction (1,20\%) and Transposition (7,78\%).In Deli Serdang Tourism Booklet, they are Adaptation (1,30\%), Borrowing (1,30\%), Discursive Creation (2,60\%), Literal Translation (79,22\%), Particularization (2,60\%), Reduction $(3,89 \%)$, Transposition $(9,09 \%)$.

3. The dominant translation technique applied in Medan and Deli Serdang Tourism Booklet" is Literal translation with frequency 197 sentences or 80,74\%. In Medan Tourism Booklet the frequency is136 sentences or $81,43 \%$ and in Deli Serdang Tourism Booklet the frequency is 61 sentences or $79,22 \%$.

There are three process in translated the dominant technique (Literal Translation) in Medan and Deli Serdang Tourism Booklet the first process is analysis, the second process is transfer and the last process is restructuring. 


\section{CONCLUSIONS AND SUGGESTIONS}

\section{Conclusions}

Having analyzed the data, it is concluded that:

1. There are ten translation techniques, not all the types of translation techniques applied in "Medan and Deli Serdang Tourism Booklet". In Medan Tourism Booklet there are 8 techniques, namely adaptation, amplification, borrowing, description, generalization, literal translation, reduction and transposition. In Deli Serdang Tourism Booklet there are 7 techniques, namely adaptation, borrowing, discursive creation, literal translation, particularization, reduction and transposition.

2. Literal translation belongs to the dominant technique in "Medan and Deli Serdang Tourism Booklet" with frequency items (80,74\%), followed by transposition $(8,20 \%)$, adaptation $(3,37 \%)$, reduction $(2,05 \%)$, borrowing $(1,64 \%)$, amplification $(0,82 \%)$, description $(0,82 \%)$, discursive creation $(0,82 \%)$, particularization $(0,82 \%)$, generalization $(0,41 \%)$.

3. There are threeprocess in translating the dominant technique (Literal Translation), the first process isanalysis, the second process istransfer and the last process is restructuring. 


\section{Suggestions}

In relation to the discussion, it is suggested that:

1. Theoretically

The findings of translation techniques in "Medan and Deli Serdang TourismBooklet" should encourage the readers in studying more about translation techniques.

2. Practically

For English teachers, students and researchers who are interested in the issue and motivated to get more information and knowledge about translation technique and also can be addition and comparison to the theories related to translation techniques. For the government, it is better to choose the best translator to translate the booklet because there are some sentences that are not equivalence in target language 


\section{REFERENCES}

Albir, A.H. and Lucía Molina. 2002. 'Translation Techniques Revisited: A Dynamic and Functionalist Approach". Meta: Translators' Journal, vol. 47, n 4, 2002, p. 498-512.

Ayu, N. P. I. 2011. Translation Techniques Used In Subtitle Text Of "Patch Adams" Movie: A Case Study Of The Main Character. Thesis. Semarang. Universitas Dian Nuswantoro.

Chheang, Vannarith. 2015. Tourism and Local Community Development in Siem Reap.Journal. Cambodia. Ritsumeikan Asia Pacific University.

Creswell, John. 2014. Research Design Qualitative, Quantitative, and Mixed Methods Approches. London. Sage Publication.

Newmark, Peter. 1988. A Text Book of Translation. Hertfordshire: Prentice Hall International.

Nida, Eugene, A. and Taber, Charles, R. 1982.The Theory and Practice of Translation. Netherlands: United Bible Societies.

Yulianti, Dara. 2016. Translation Techniques in English into Indonesian Novel "The Hunger Games" by Suzzane Collins. Thesis.Medan .UniversitasNegeri Medan. 